\title{
Form And Meaning Of Dayak Traditional House In East Kalimantan, Indonesia (Case Study: Lou Pepas Eheng Dayak Benuaq's House)
}

\author{
Laksmi Kusuma Wardani \\ Interior Department, Petra \\ Christian University \\ laksmi@petra.ac.id
}

\author{
Ronald Hasudungan \\ Irianto Sitindjak \\ Interior Department, Petra \\ Christian University \\ ronald_his@petra.ac.id
}

\author{
Poppy F. Nilasari \\ Interior Department, Petra \\ Christian University, \\ popie@petra.ac.id
}

\author{
Devina Faustine \\ Widjayadi \\ Interior Designer \\ WIDEproduction \\ devinafw@gmail.com
}

\begin{abstract}
East Kalimantan has 74 family tribes out of 405 Dayak family tribes in Kalimantan. In the past, the dwellings of Dayak tribes were known as lamin or amin (Dayak Kenyah), luuq (Dayak Tunjung) or lou (Dayak Benuaq). This research aims to specifically discuss about the Dayak traditional house with lou Pepas Eheng Dayak Benuaq as the research object. The research uses the Erwin Panofsky's method of Iconology to analyse the hidden meaning of the architectural and interior form configurations of Lou Pepas Eheng. Based on the analysis of data, findings reveal that the hidden meanings behind lou relate to the cosmology of the Dayak tribe regarding the harmony of human life with the universe. A house is the embodiment of the process of human life from birth till death, a representation of family values, gotong royong (an Indonesian cultural term for assisting each other), unity and social life. It is also a representation of the physical values of domestic protection and safety. A house is also a spiritual symbol of life views, norms, beliefs, philosophies and local genius of the Dayak Benuaq society that can be symbolically analysed from the building form, spatial organisation and containments.
\end{abstract}

Keyword: Pepas Eheng, Hidden Meaning, Vernacular Architecture, Symbolic House

\section{INTRODUCTION}

Dayak is a term for indigenous people in the inland of Borneo. The word comes from the Iban Dayak language that means "human." In addition there are those who interpret the term as "inland" or "upstream" (Dinas Pariwisata \& Budaya Kutai Kartanegara, 2006: 33). Dayaks or also called Landers or Daye are native Kalimantan people who spread and live in the inlands or mountains. In the past, there were wars between tribal groups as an effort to seek influence and maintain one's existence. As a result, Dayak people have spreaded throughout the island of Borneo, forming cultural organizations in small groups or tribes that live together. The Dayak tribe has more than 405 sub-tribes consisting of 8 large tribes and 18 small tribes.

In East Kalimantan itself, there are 74 tribes of kinship (Riwut, 1993: 234). Currently, the wellknown tribes in East Kalimantan are Dayak Benuaq, Tunjung Dayak, Bahau Dayak, Penihing Dayak, Modang Dayak, Bentian Dayak, Basap Dayak, Punan Dayak, Dayak Kayan, Dayak Kenyah, Dayak Berusu, Dayak Lundaye, Dayak Long Glat, Dayak Labbu, Dayak Tenggalan, and Dayak Segai. Each tribe has distinctive cultural arts that are interesting to study, including the art of building, in the form of dwelling houses.

The Dayak Benuaq tribal house is called lou or lamin in Malay Kutai language or amin (Dayak Kenyah language). It is a long stilted dwelling that houses 10-30 heads of households or even more with one lineage and live together in one roof. This lou would grow longer with the addition of new families (Laxman Joshi et all., 2004: 2). Lou consists of dwelling spaces divided by walls, separating one family from another. The front part of the dwelling space is a longitudinal empty space that is used as a gathering place for families and traditional ceremonies. This traditional house contains a variety of meanings, not only as a shelter, but also as a representation of the way of thought, life principles, and ideas that are typical of the Benuaq Dayak tribe who live in it. Lou is the totality of the physical results of the activities, actions and work of the Dayak people. Building lou means building and accommodating cultural activities that contain the values of unity, togetherness, solidarity, a sense of tolerance, responsibility for oneself, family, society, the universe and God Almighty. These values form the basis of the consideration for this research, as lou contains moral values, beliefs, and cultural wisdom of the ancestors of the Benuaq Dayak tribe which are interesting aspects to study further.

\section{LITERATURE REVIEW a. A Brief History on Dayak Benuaq tribe}

The Benuaq Dayak are part of the Luang Dayak group, who together with Dayak Ngaju, Ot Danum, and Ma'ayan, formed the Southeast Borneo Barito family language (Haug, 2007: 10). Most Benuaq people call themselves 'Dayaks', not 'Luangan', as a differentiator from the Muslim population of East Kalimantan and also call themselves 'Benuaq' to differentiate themselves from other Dayak groups. When they meet with fellow Benuaq people, they usually introduce themselves by calling the river located at the place where they live, for example Benuaq Idaatn or Benuaq Ohookng (Haug, 2007: 11). 
According to sources from Mollinckrodt's research based on the similarity of farming tools, hunting tools, war equipment and traditional ceremonies of death, and worship of ancestral spirits, it can be assumed that the Benuaq Dayak tribe originated from Central Kalimantan, in particular, a border area between Cetral Kalimantan and Sarawak (Departemen Pendidikan dan Kebudayaan, 1982: 31). At their place of origin, they were called the "Luangan" tribe. Because of the natural conditions and the pressure of the Ibans from the North, they moved away from their lands of origin and finally reached the East Kalimantan-Kutai Regency (Departemen Pendidikan dan Kebudayaan, 1982: 31). After arriving at East Kalimantan-Kutai Regency, their names were changed to "Benuaq", derived from the name of the place "Benuaqkn", as according to their own tribal stories.

The place was originally inhabited by the Benuaq Dayak tribe named Bombay or Benuaqkn. They settled and developed themselves in Bombay. There was a belief in the Benuaq Dayak tribe regarding the place: there cannot be more than 40 youths. If there were more than 40, they must move elsewhere. Hence, around three hundrerd years ago a migration movement took place in which some of the people moved towards the Kedang Pahu river, some towards the Nyuatan River, and others toward the Idaatn River. The Dayak tribe who migrated to the Kedang Pahu River, initially settled on Muara Pahu, but because of Islamic influence they moved inland towards the Kedang Pahu River, in Muara Lawa sub-district, Big and Small Bentian sub-district, and Damai subdistrict, of which there was a village called Jengan Danum which means watery tree. There were indeed many trees that contained water and were resistant to water, such as Bengkirai trees. As for the Dayak tribe who migrated towards the Nyuatan river, they headed to a place called Senteaau, according to the name of a village in their place of origin in Central Kalimantan. From here they spreaded to Jempang subdistricts, such as Mancong and Tanjung Isuy villages, to Muara Muntai sub-districts such as Ohookng and Lamin Prigi. While the Dayak tribe who migrated to the Idaatn River spreaded to the Muara Wahau sub-district, and among them there was a village called Dempar. From these places, there were those who eventually reached Sebulu and Tenggarong districts (Departemen Pendidikan dan Kebudayaan, 1982: 31).

In 1981 till 1983 the population of the Benuaq community was estimated to be between 20,000 and 23,400 people. Based on the 2001 research report, they inhabited the area stretching from Bongan in the east across the lake Jempang to the Tunjung highlands in the north to the area opposite the Kedang Pahu drainage area to the Teweh tributaries in Central Kalimantan (Haug, 2007, 11).

\section{b. Cosmological System of Dayak Benuaq Tribe}

The original beliefs of the Benuaq Dayak tribe before the arrival of Catholicism and Christianity in
Kalimantan was animism and dynamism, referred by the Central Kalimantan Dayak tribe as "Kaharingan" religion. Kaharingan people believe that the environment is full of spirits: spirits that occupy the pillars of houses, rocks, trees and rivers (Bonoh, 1985: 18).

As according to animistic beliefs, the Dayaks strongly believed that humans consisted of both evil spirits and good spirits. There are spirits that give goodness, there are spirits that are destructive, and there are spirits that disturb other creatures. A good spirit is a spirit that does many good things during its lifetime, while an evil spirit is a spirit that during many lifetimes does a lot of evil and disturbs other beings. These spirits live in a place called Mount Lumut which is a place that is considered sacred. The people believed that Mount Lumut was the first place where humans were created and the place of return for humans after death (Departemen Pendidikan dan Kebudayaan, 1982: 37).

In the dynamism beliefs, the Dayaks believed that the flora and fauna or the natural surroundings have the power to spread happiness or misery to their lives. For example, if there is a honey bee in the middle of the field, it is a sign of death. On the contrary if there are ants and anai-anai (a type of larva or termite) in the middle of the field, it is a sign that they will be blessed with many crops. Banyan trees were considered sacred trees because they were believed to be places where evil spirits lived. That is part of the original Dayak tribal beliefs in the past. Although Catholic and Christian religions carry cultural acculturation that was positively accepted by Dayak tribes, they were still bounded by dynamism beliefs. This is evident in the preservation of traditional ceremonies such as death ceremonies (kwangkai) and pelas kampung ceremonies or cleaning the village (Ngugu ceremony). These ceremonies were usually led by Kepala Adat (custom chiefs), Pewara and Belietn (Departemen Pendidikan dan Kebudayaan, 1982: 38). Ceremonies carried out by the Benuaq Dayak tribe include life rituals (birth, healing, peace, marriage) and rituals of death (param api, kenyau, kwangkai ceremonies) (Emanuel, Dyson, and Matthew, 2013: 44).

\section{c. Dayak Benuaq Tribe Traditional Dwelling}

The Benuaq Dayak society in the past, mostly lived in long houses. Nowadays, however, the village community has developed into houses in which each of them is inhabited by one family independently. However, some villages still maintain the longhouses that are usually used for meetings and large ceremonies, and have also become objects of tourist attraction (Haug, 2007: 10). The form of the dwellings usually extend to the river banks or to the right and left of the village's access road. In addition, due to the use of the river as a transporation channel, most houses line along the river. The distance between one house to another is about 2-5 meters (Departemen Pendidikan dan Kebudayaan, 1982: 32). There are houses in the form of 
single houses and some in the form of long houses. There are also rice barns, schools and simple shrines. The lou is a big house consisting of rooms inhabited by a family consisting of fathers, mothers and children and is inhabited by one to five or even more friends of families, which consists of one senior-trained family and a children-trained family, both male and female. Trained families are families consisting of a father, mother and child plus other family members such as grandmother, grandfather, niece, uncle, and aunt (Bonoh, 1985: 9)

The Benuaq Dayak tribe's house known as Lou, is a pit-house with sturdy poles that use ironwood material. The walls were made of planks or bark, while the roof consisted of shingles; some used wood and there were others that used leaves. The floor was a board or bamboo: a feature of ordinary people's homes. The height of the house was usually 3-4 meters, with length between 25-50 meters, and width between 8-10 meters. The position of the house usually faces the sunrise with its back facing the west. This position has a purpose, based on their beliefs that were related to the nature of life (Departemen Pendidikan dan Kebudayaan, 1982: 32). In the book "Lungun dan Upacara adat", it was stated that the long houses were made of wood with its bollards as high as 5-7 meters. Lou functioned as a place for traditional ceremonies (Bonoh, 1985: 10). Lou was usually decorated with metaphors of channels, in the form of circular leaves that locals call Jautn Nguku. While the winding leaves were called Wakai Rurut. In general, those parts that were decorated were the main pillars and the columns located at the front or listplang. All the decorations have meanings: as a repellent of welfare or symbol of prosperity (Departemen dan Kebudayaan, 1982: 33).

\section{PROBLEM STATEMENTS}

The wealth of Dayak cultural arts in the form of traditional buildings, is one of the national assets that can strengthen the identity of the Indonesian people as a nation of Unity in Diversity. Apart from its beauty in terms of form, the philosophy behind the form is a reflection of the richness of Indonesian culture. The unity of house and culture is manifested in the architecture of its traditional house that integrates all the activities of human life that live in it (Soeroto, 2007: 11). Ideas, way of thoughts and cultural activities are embodied in the form of the house building and hence form the basic consideration of this research. This study aims to discover hidden meanings and the cultural wisdom behind the architecture of the Benuaq Dayak house, taking the Pepas Eheng Dayak Benuaq house in West Kutai as the case study.

\section{METHODOLOGY}

This research is a case study research. The object chosen for this research was the Pepas Eheng house, on the basis that the Eheng Pepas represented the house of the Benuaq Dayak tribe which is still used for domestic activities of the Benuaq Dayak community until today. The data were collected through interviews, field observations, and literature reviews. The analytical method used was descriptive analysis with the iconographic approach by Erwin Panofsky.

Iconography is a method of study that takes into account the configuration of images in a work to find out hidden meanings. This method consists of three consecutive stages as follows:

1. Pre-iconographic description: the identification of the visual form and meaning of the expression.

2. Iconographic analysis: analysis of visual elements that studies the world of images, emblems and symbols by taking into account the history and social conditions of the people at a particular time.

3. Iconological interpretation: understanding the intrinsic meaning or essence of hidden content / value.

The three stages have a prerequisite relationship from one stage to another (Panofsky 26-40).

\section{FINDINGS}

Lou Pepas Eheng was founded in 1962. Its location is in the Peng Eheng village, Barong Tongkok subdistrict, West Kutai in East Kalimantan. Lou Pepas Eheng is protected by Law No. 11 of 2010 as a cultural heritage building, established by the Ministry of Education and Culture, Directorate General of Culture, Samarinda Cultural Preservation Center, Kalimantan Working Area. The people who live in this lou are the indigenous Benuaq Dayak tribe consisting of 32 families. The users consist of men who work as factory workers and some who work in the fields, while the women work as craftsmen of woven rattan for anjat. In the lou, there is also a ceremony handler who is still active in performing traditional ceremonies at certain events.

Figure 1. Façade form of Lou Pepas Eheng (Photo: Laksmi, 2018)

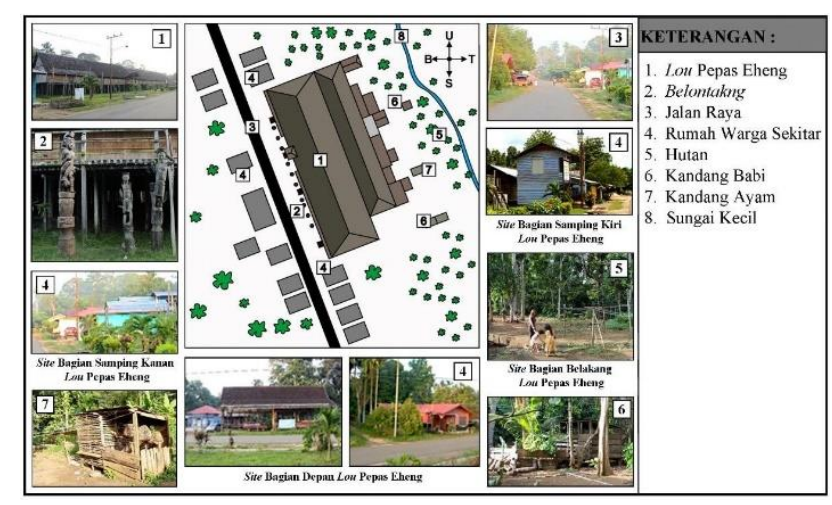




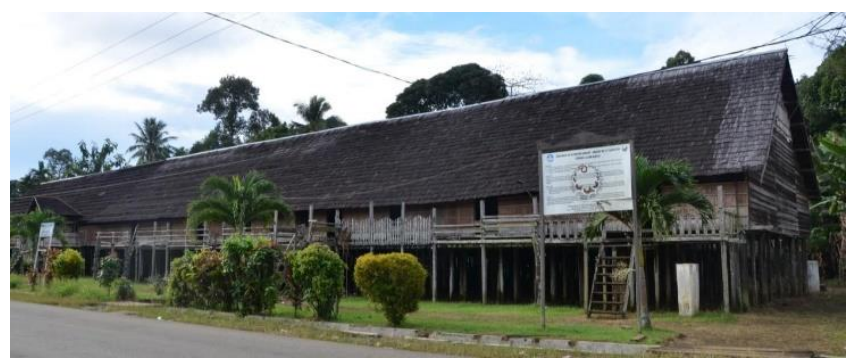

Figure 2. Situation of the Lou Pepas Eheng site and the surrounding buildings

(Photo: Devina Faustine, 2016)

Lou Pepas Eheng faced southwest and was located in the upstream areas of the river. The lou was a very large long building and was the center of other buildings surrounding it. It was a stilt house and consists of three structures, namely kolong (under), badan (body) and atap (roof). The stilts (kolong) were the lowest part of the building that were supported by 96 columns. The diameter of main column was $25-30 \mathrm{~cm}$ and there were poles (tempoor) with diameter of $7-10 \mathrm{~cm}$ from ironwood. These poles were mounted from the ground with a depth of about $1-1.5$ meters, while the height of the poles from the ground to the ceiling of the lou was about 2 meters. The underside was used to support buildings, store firewood, and park vehicles. In this area, pets such as dogs, pigs and chickens often roamed about.

The body part was the middle part of the building as well as the main place for the activities of the inhabitants. This section consisted of three main rooms, namely the foyer, ceremonial room, and living space called orook. The ceremonial room is located in the middle of the body part of lou. The ceremonial room was an empty space like a long hallway which was commonly used for traditional ceremonial rituals. During the ceremony, the room was used by the cerominal handlers who dance around and perfom rituals with various ceremonial equipment. In addition, the ceremonial room was very crowded with the presence of guests and relatives from other villages who were also invited to attend the procession. At the time the traditional ceremony took place, the ceremonial room was the place for guests to stay and they slept using lampit or apai jaliq (woven mats for sleeping). On normal days if there were no traditional ceremonies, the ceremonial space became a passage to the village. Meanwhile their activities during the day include lying in bed or socializing between families who lived in each orook which were also places for children to play. The females like to weave rattan for anjat.

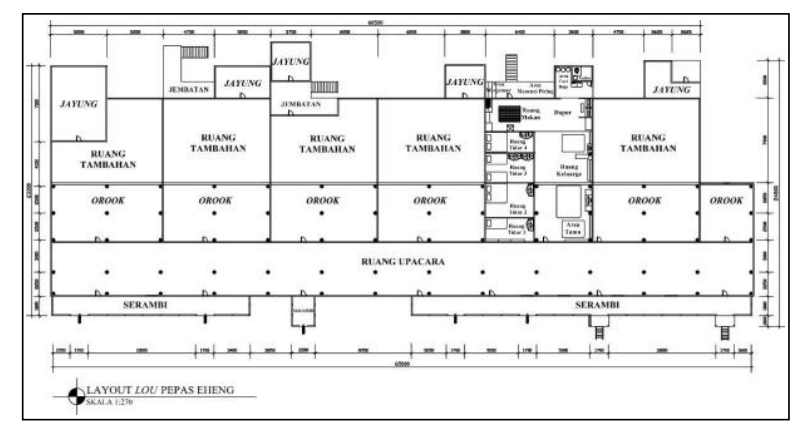

Figure 3. Lay out of Lou Pepas Eheng (Picture: Devina Faustine, 2016: 152).

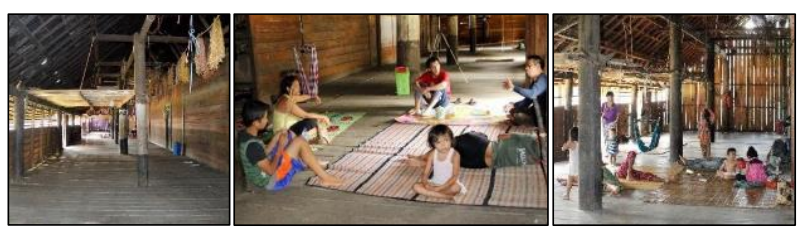

Figure 4. Atmosphere of the ceremonial room of Lou Pepas Eheng during the day

(Photo: Devina Faustine, 2016)

Floors and walls used wooden boards arranged vertically and horizontally. The overall spatial form, repetition of the roof structure lines from the roof frame (sempayetn) to the wall (batakng Bungan) became the natural decorations of the ceiling and walls. This ceremonial room had seven doors that connected the ceremonial hall with the porch and another seven doors that connected the ceremonial room with orook. In addition there were five windows with a width of $75 \mathrm{~cm}$ and a height of $120 \mathrm{~cm}$. Along the upper wall there were opening lattices through which air and sunlight can enter the ceremonial space. The rhythmic lines of natural light makes the room visually attractive.

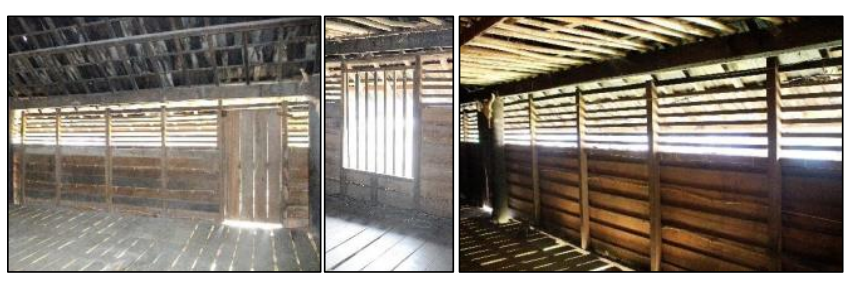

Figure 5. Doors, windows and lattices in the ceremonial room (Photo: Devina Faustine, 2016).

At the top of the ceremonial room, there was an attic resembling a $5 \times 2$ meter rack made of round sungkai wooden assemblies that were hung from the roof frame. This space functioned as a place to store ceremonial equipment. In the ceremonial room there was a decorative element of the buffalo skull. The skull of the buffalo's head was tied to the ori in front of the orook who had performed the buffalo cutting ceremony. In addition, this ceremonial room was decorated by fringes placed on the roof frame (sempayetn). 


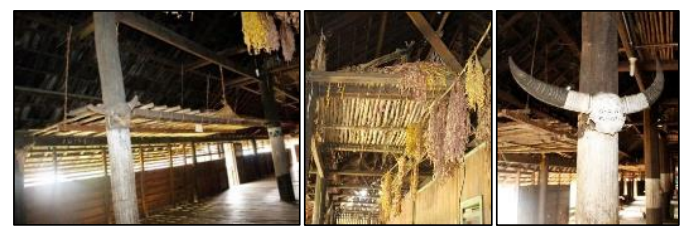

Figure 6. Attic, fringe and meditating place, as well as a buffalo head skull hung on the column (Photo: Devina Faustine, 2016)

Orook was the most private place of the lou to perform household activities. It was inhabited by four family heads. Orook belongs to the ceremonial handler. The room was divided into areas to receive guests; in this case guests who can enter the orook were families but also with the permission of the owner of the orook, sleeping spaces that were partitioned and given mosquito nets, family rooms to watch $\mathrm{TV}$, and connected with the jayung section. The floors on the orook consisted of a wooden board covered with vinyl or plastic carpet. There was levelling between the orook and the jayung. The dividing wall between the orook was from triplex material with a wooden beam frame.

Other supporting elements in the orook consisted of a door that connected the orook with the ceremonial room and the lattice at the top of the wall. The lighting system on the orook relied on sunlight entering through the lattice section and was assisted by artificial lighting from lamps. During the ancient times, the people used traditional lamps from burning meranti sap called a pelita. There were also wardrobes, tv cabinets, tilam (thin mattresses from kapok), unan (pillows), unan mooq (bolsters), mosquito nets (thick cloth) that were believed to be able to protect the inhabitant from evil powers and spared from mosquitoes. Some heirlooms include ceremonial equipment (jars from pottery), mandau (typical Dayak weapons) stored in cabinets, and so on. The orook was not given a decorative element.

The roof was the uppermost part of the building. The roof in the main building was in the form of a gable and there was a combination of gable shapes that stand out on the porch. Secondary buildings also used gable roofs which were sometimes connected to a flat-shaped roof called jayung. The roof of the lou Pepas Eheng was made of sapo tipaak which were arranged in the opposite direction of each row. The triangular roof wall part was also covered with bire. On the roof of the main building there was a simple decorative element called bangkong in the form of a protrusion from the penyempetn that crossed and was carved in the likeness of a bird's wing. In the penyempetn section of the main building, there was also ampetn which were pointed like the tip of a chopsticks. On the roof of the secondary building there were also bangkong decorative element that had a diamond shape like a spearhead. On the inside of the roof there was a meditation room that could be accessed from the inside of orook. The room was made of rounded sungkai wood with a fastening and laying construction on the sempayetn. All the orook of lou Pepas Eheng had a meditation room at the top. The meditation room was a prayer room for ceremonial handlers for the benefit of preparing traditional ceremonies.

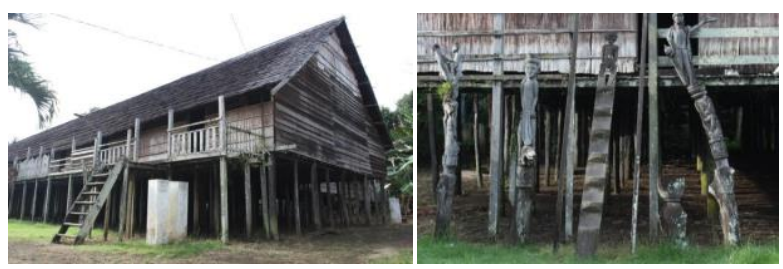

Figure 7. Side corner of the lou building and with statues at the front (Photo: Laksmi, 2018)

At the front of lou there were statues (sepatukng) that were called belontakng. Belontakng were made from teluyetn (ironwood) which had a height varying from $70 \mathrm{~cm}$ to 2 meters from the ground surface with a diameter of 30-50 cm which were mounted from inside the ground. The statue was not coated and maintained the natural color of ironwood. There statues of human figures with different poses and some were added with attributes such as clothes and headbands, along with some animals or urns with plant carvings. This belontakng made up the decorative elements of lou Pepas Eheng architecture. There are currently 10 pieces of belontakng in front of lou Pepas Eheng, indicating that the inhabitants of this lou had performed at least 10 traditional buffalo cutting ceremonies.

\section{DISCUSSION}

Research on meanings of traditional buildings will always be related to the beliefs and life views of the local community regarding the formation of the universe. The unity between the house, activities, and life views of its inhabitants in perfoming their culture is reflected in the site, building forms and spatial organization.

\section{Description of Pre-Iconography dan Iconography}

\begin{tabular}{|c|c|c|c|}
\hline \multicolumn{3}{|c|}{ Pre-Iconography } & \multirow{2}{*}{$\begin{array}{c}\text { Iconography } \\
\text { (Contextual } \\
\text { Meaning) }\end{array}$} \\
\hline & Factual & Meaning of Expression & \\
\hline $\begin{array}{l}\text { Buildin } \\
\text { g Site }\end{array}$ & $\begin{array}{l}\text { - Building } \\
\text { faces } \\
\text { southwest } \\
\text { - Located in } \\
\text { the forest } \\
\text { and hilly } \\
\text { areas } \\
\text { - Near a } \\
\text { small river } \\
\text { and } \\
\text { upstream } \\
\text { - Facing the } \\
\text { highway }\end{array}$ & $\begin{array}{l}\text { - Consideration of letting } \\
\text { sunlight illuminating } \\
\text { the entire interior of the } \\
\text { building. } \\
\text { - The direction } \\
\text { determinant is parallel } \\
\text { to the direction of the } \\
\text { river flow } \\
\text { (upstream to } \\
\text { downstream) } \\
\text { - Ease of access and } \\
\text { mobility of activities }\end{array}$ & $\begin{array}{l}\text { - Rivers are a } \\
\text { sources of } \\
\text { life and } \\
\text { blessing } \\
\text { from where } \\
\text { all the } \\
\text { necessities } \\
\text { of life are } \\
\text { obtained } \\
\text { (food, } \\
\text { drinking } \\
\text { water, } \\
\text { cooking } \\
\text { needs, } \\
\text { sanitation, } \\
\text { transportatio } \\
\text { n circulation } \\
\text { channels, } \\
\text { and as } \\
\text { sources of } \\
\text { income). } \\
\text { - Good water } \\
\text { brings good }\end{array}$ \\
\hline
\end{tabular}




\begin{tabular}{|c|c|c|c|}
\hline & & & $\begin{array}{l}\text { life for the } \\
\text { house } \\
\text { - Symbol of } \\
\text { welfare and } \\
\text { land fertitility }\end{array}$ \\
\hline \multirow[t]{4}{*}{$\begin{array}{l}\text { Buildin } \\
\text { g } \\
\text { Form }\end{array}$} & \multirow[t]{2}{*}{$\begin{array}{l}\text { Top: saddled } \\
\text { roof and } \\
\text { sirap sapo } \\
\text { tipaaq }\end{array}$} & $\begin{array}{l}\text { Protection from heat, sun } \\
\text { and rain (functional) }\end{array}$ & $\begin{array}{l}\text { - Sacred, } \\
\text { describing } \\
\text { the nature of } \\
\text { the Creator's } \\
\text { place above }\end{array}$ \\
\hline & & & $\begin{array}{l}\text { - Vertically, a } \\
\text { symbol of a } \\
\text { strong and } \\
\text { firm } \\
\text { protection } \\
\text { against all } \\
\text { living } \\
\text { conditions } \\
\text { - } \\
\text { Horizontally } \\
\text {, the form of } \\
\text { the gabled } \\
\text { roof shows } \\
\text { spiritual } \\
\text { unity } \\
\text { altogether }\end{array}$ \\
\hline & $\begin{array}{l}\text { Middle: } \\
\text { shape } \\
\text { extending } \\
\text { from east to } \\
\text { west, } \\
\text { repetition of } \\
\text { wood } \\
\text { material } \\
\text { pattern, } \\
\text { natural }\end{array}$ & $\begin{array}{l}\text { A place for daily human } \\
\text { activities as well as a } \\
\text { tourist } \\
\text { attraction }\end{array}$ & $\begin{array}{l}\text { - Vertically, } \\
\text { the symbol } \\
\text { of human } \\
\text { life in } \\
\text { togetherness } \\
\text {, living side } \\
\text { by side in } \\
\text { harmony. } \\
\text { Horizontally } \\
\text {, describes } \\
\text { the process } \\
\text { of life in the } \\
\text { world from } \\
\text { the } \\
\text { beginning to } \\
\text { the end of } \\
\text { life }\end{array}$ \\
\hline & $\begin{array}{l}\text { Bottom: } \\
\text { consists of } \\
\text { supporting } \\
\text { poles } \\
\text { embedded in } \\
\text { the ground }\end{array}$ & $\begin{array}{l}\text { Support for burden. } \\
\text { A place for animals } \\
\text { under the house and } \\
\text { parking space }\end{array}$ & $\begin{array}{l}\text { Profane, } \\
\text { describes the } \\
\text { underworld }\end{array}$ \\
\hline $\begin{array}{l}\text { Spatial } \\
\text { Organiz } \\
\text { ati on }\end{array}$ & $\begin{array}{l}\text { Spatial Zone, } \\
\text { there are } 3 \\
\text { zone } \\
\text { categories }\end{array}$ & $\begin{array}{l}\text { - Public: Porch } \\
\text { - Semi-public: } \\
\text { Ceremonial Room } \\
\text { - Private: Orook and } \\
\text { Jayung lou }\end{array}$ & $\begin{array}{l}\text { - Public and } \\
\text { semi-public } \\
\text { zones } \\
\text { describe the } \\
\text { value of } \\
\text { openness } \\
\text { and } \\
\text { togetherness } \\
\text { - Private and } \\
\text { semi-public } \\
\text { zones } \\
\text { represent } \\
\text { intimacy in } \\
\text { social } \\
\text { relations and } \\
\text { ethics of } \\
\text { politeness }\end{array}$ \\
\hline
\end{tabular}

\begin{tabular}{|c|c|c|}
\hline $\begin{array}{l}\text { Nature of } \\
\text { Space, there } \\
\text { are } 3 \\
\text { classification } \\
\text { s of spatial } \\
\text { character }\end{array}$ & $\begin{array}{l}\text { - Sacred: Ceremonial } \\
\text { Room } \\
\text { - Profane: Porch and } \\
\text { Jayung } \\
\text { - Transition from profane } \\
\text { to sacred: Orook }\end{array}$ & $\begin{array}{l}\text { The flow of } \\
\text { circulation in } \\
\text { the lou is a } \\
\text { linear } \\
\text { circulation } \\
\text { flow, } \\
\text { designed } \\
\text { according to } \\
\text { the formation } \\
\text { of nature as } \\
\text { their } \\
\text { transportatio } \\
\mathrm{n} \text { medium: } \\
\text { the river flow } \\
\text { from } \\
\text { upstream to } \\
\text { downstream. }\end{array}$ \\
\hline $\begin{array}{l}\text { Linear } \\
\text { Circulation }\end{array}$ & $\begin{array}{l}\text { the flow of river and } \\
\text { transportation that is } \\
\text { linear }\end{array}$ & $\begin{array}{l}\text { The design of } \\
\text { circulation } \\
\text { flow in lou is } \\
\text { in harmony } \\
\text { with the } \\
\text { natural } \\
\text { surroundings. }\end{array}$ \\
\hline
\end{tabular}

\section{Iconological Intepretation (Philosophical Value) \\ 2.1. Building Site}

The Dayak Benuaq tribe believe in Perejadiq Bantikng Langit, the Creator, who lives above of the skies, a sacred place kwown as Langit Usuk Wari. Perejadiq Bantikng Langit was given the title Latala which means "the light of the world." The bright place of the world was depicted by the location of the rising sun and hence the east was regarded as the most sacred and noble place. Conversely, the darkest place in the world was believed to be the direction of the sunset which is the west. The Dayak community's belief that the west direction depicts death, a place of all sadness (sorrow), all abstinence, the causes of bad luck and curses while the east is the symbol of birth, new spirit, joy, and blessings (Emanuel, Dyson, Matthew, 2021; 34- 38).

The Dayak people's belief regarding the origin of life was influenced by the geographical conditions of their dwellings which were dominated by forests and had many large rivers surrounding them. The Benuaq Dayaks believed in the existence of a tree of life, where from that tree the life of the universe appeared. The tree of life was called the Putaakng Kayutn Naing. This tree was made by the Creator by uniting the Bengkolokng Langit (Sky) with Belukeetn Tana (Earth). Putaakng Kayutn Naing tree was a representation of the dwelling house of the Dayak Benuaq tribe: the strong and firm lou (Emanuel, Dyson, and Matthew, 65). Lou was a representation of the unity between heaven and earth like the Putaakng Kayutn Naing tree. From the hole of the Putaakng Kayutn Naing tree flow the water that supports all creation (Emanuel, Dyson, Matthew, 2013: 11). The tree hole represented the center of the source of life, like running water. Therefore, the Benuaq Dayaks believed that water was an important source of life for them. This belief influenced the idea to build lou by considering the direction of the building and the 
proximity of lou to the river as a source of life. The building orientation of lou also reflected the rotation of the sun (rising in the east and sinking in the west)

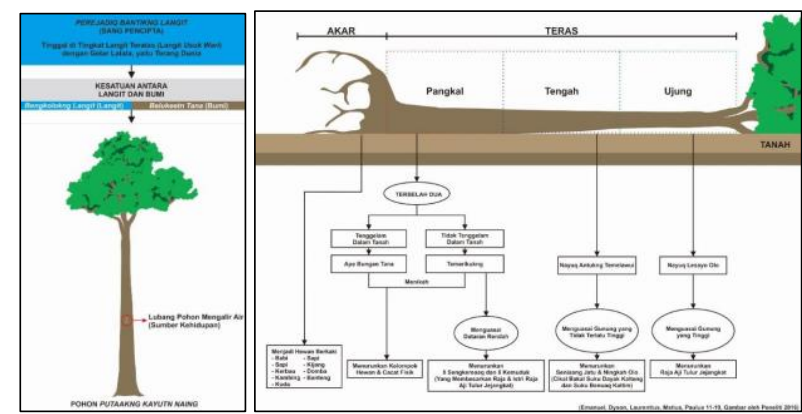

Figure 8. Chart illustration of the story of Putaakng Kayutn Naing tree

Based on the above description, the elements of the universe, namely the sun, water, and land were taken into consideration in terms of the direction of the building and the choice of building location. This provided an understanding that the harmony with the universe was a consideration that brings blessings to the inhabitant of the house.

\subsection{Building Form}

In general, traditional houses were built with the concept of harmony between the universe and the life views of their inhabitants. Houses were treated as micro cosmos (nature) that must be in harmony and balanced with the macro cosmos (universe). Vertically, the traditional building form of the Dayak house was a stage that consisted of three parts, namely the head (roof), body, and feet (under). Lou was a house that has the shape and structure associated with the universe mounted on a pole (pile dwelling) which was divided into three parts. The roof is a sacred upper structure that described the nature on the place of the Creator, the place of the gods, and ancestoral spirits. The body was the structure in the middle part of the building that articulated the place of human life in the world, and the foot (under) is the lower structure that articulated the underworld where animals and fowl things crept (Soeroto, 2007: 22).

The building can also be analysed horizontally, interpreted as a picture of the universe, in which the eastern part of the building depicted the rising of the sun and the western part of the building depicted the sunset. This can be concluded through the belief that the rising sun was a symbol of the beginning of life, new enthusiasm, blessings, and joy while the sun setting down was a symbol of the end of life, a place of misfortune, curse and sorrow. This belief was also reflected in the process of pesengkeet puaas utaas traditional rituals in the lou (Emanuel, Dyson, Matthew, 2013: 35-39). Hence the lou was the representation of the universe that applied the direction of the moving sun above the building even though the building does not exactly extend in the east and west directions.

In addition, the shape of the lou that extended from the western part of the building to the eastern part of the building illustrated the horizontal relationship between one another.

\subsection{Spatial Organisation}

The spatial organization in the body area of lou was divided into three main pillar relationships:

the most sacred relationship to God; relationships with others both public togetherness and private relations (intimacy); and relationships with the environment. The ceremonial space became a central space as a connecting area between relations where various functions of social relations occur within.

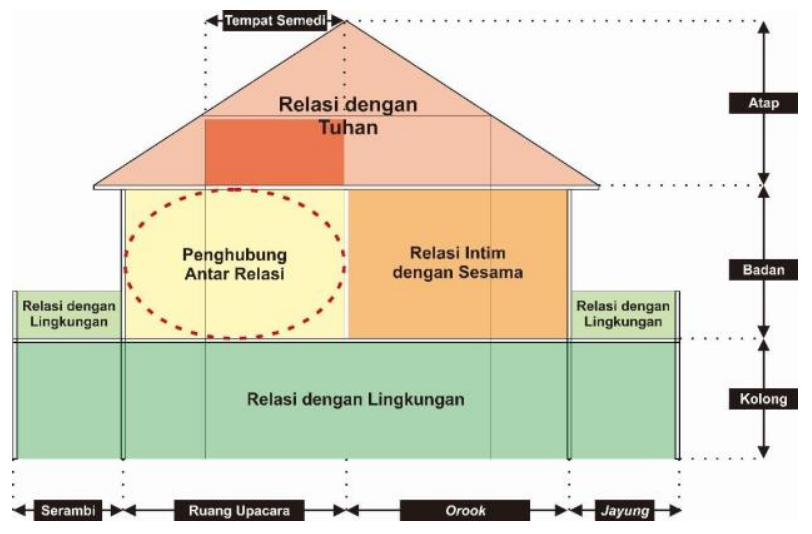

Figure 9. The meaning behind the vertical spatial organization of lou (Figure: Devina, 2016)

In the lou, there was also a place for meditation that acted as an intermediary space (medium) to the sacred level, an articukation of humans trying to reach the level of divinity sympbolised through the roof. The meditation room was a space formed in connection with the system of beliefs of the Benuaq Dayaks who believe that by praying there would be goodness and blessings for household of the lou in the form of protection, peace and prosperity.

As a whole, the spatial organization of lou considered the functional aspects related to the beliefs, ethics of politeness, and the philosophy of life adopted by the Benuaq Dayaks about the three main relationships: the relationship with the Creator (spiritual), the relationship with others (togetherness and intimacy), and the harmonious relationship with the natural surroundings.

\section{CONCLUSION}

The lou traditional house was a building that reflected the wisdom of the Dayak Benuaq people. Even till today the house is still inhabited and maintained. Lou, as a physical form, became a medium for expressing the language from the life views of the Dayak Benuaq people regarding the unity of vertical relationships (the upper realm, the middle / world realm, and the lower realm) and horizontal relationships (human life cycle in a safe, harmonious and peaceful atmosphere together). Lou became a symbol of the human being both spiritually and physically (micro cosmos) in harmony with the universe (macro cosmos). Thus, the meaning of lou cannot be separated from the beliefs of the Dayak tribe regarding the harmony of 
human life with God, fellow humans, and the universe. In addition, lou Pepas Eheng was a representation of the process of human life from birth to death, reflecting ideas about family values, mutual cooperation, unity and social life of society, as well as representation of the value of physical protection and security. The house became a spiritual symbol of the people's life views, norms, beliefs, philosophical values, and the idea of the local wisdom of the Dayak Benuaq society, arcticulated through the building form, organization of space, and its contents.

\section{ACKNOWLEDGEMENTS}

This research was funded by the Penelitian Dasar Unggulan Perguruan Tinggi grant from the Ministry of Research, Technology and Higher Education, Republic of Indonesia.

\section{REFERENCES}

Bonoh, Yohanes. Lungun dan Upacara Adat. Kutai Kartanegara: Permuseuman Provinsi Kalimantan Timur, 1985.

Departemen Pendidikan dan Kebudayaan Direktorat Jendral Kebudayaan. Fungsi Patungpatung Tradisional Suku Dayak Benuaq. Laporan Penelitian. Tenggarong: Museum Negeri Propinsi Kalimantan Timur Mulawarman, 1982.
—. Kajian Semiotik Ornamen Interior pada Lamin Dayak Kenyah (Studi Kasus Interior Lamin di Desa Budaya Pampang). Tenggarong: Museum Negeri Propinsi Kalimantan Timur, 1982.

—. Rumah Adat Suku Dayak Tunjung "Lamin". Samarinda: Museum Negeri Propinsi Kalimantan Timur, 1982.

Departemen Pendidikan dan Kebudayaan. Upacara Tradisional (Upacara Kematian) Daerah Kalimantan Timur. Jakarta: Proyek Inventarisasi dan Dokumentasi Kebudayaan Daerah, 1984.

Dinas Pariwisata \& Budaya Kutai Kartanegara. Discover Kalimantan Genuineness. Kutai Kartanegara: PT Alam Tekindo Lestari, 2006.

Emanuel, Laurentius Dyson dan Paulus Matius. Sejarah dan Mitologi Suku Asli Kalimantan Timur. Kutai BaratKalimantan Timur: Citra Wacana, 2013.

Haug, Michaela. Kemiskinan dan Desentralisasi di Kutai Barat: Dampak Otonomi Daerah Terhadap Kesejahteraan Dayak. Research Report. Bogor: Center for International Forestry Research, 2007.

Laxman Joshi, Kusuma Wijaya, Martua Sirait, Elok Mulyoutami. "Indegenous System and Ecological Knowledge Among Dayak People in Kutai Barat, East Kalimantan.” ICRAF Southeast Asia Working Paper (2004): i-22.

Riwut, Tjilik. Kalimantan Membangun Alam dan Kebudayaan. Yogyakarta: PT. Tiara Wacana Yogya, 1993.

Soeroto, Myrtha. Dari Arsitektur Tradisional Menuju Arsitektur Indonesia. MYRTLE Publishing, 2007. 